\title{
Erratum to: Development of an Automated Precision Direct Current Source for Generation of pA Currents Based on Capacitance Charging Method at CSIR-NPL
}

\author{
B. Ehtesham*, P. S. Bist and T. John
}

LF HF Impedance and DC Standards, ALSIM, CSIR-National Physical Laboratory, New Delhi 110012, India

Published online: 21 February 2017

(C) Metrology Society of India 2017

Erratum to: MAPAN-Journal of Metrology Society

of India

DOI 10.1007/s12647-016-0186-0

Few entries in Table 5 were incorrect in the online pub-

lished article.

The correct table is given below (Table 5).

The original article has been updated accordingly.

Table 5 Uncertainty evaluation

\begin{tabular}{|c|c|c|c|}
\hline Uncertainty contribution in current measurement & $100 \mathrm{pA}$ & $10 \mathrm{pA}$ & $1 \mathrm{pA}$ \\
\hline 1. Due to ramp & $10 \mathrm{fA}$ & $1 \mathrm{fA}$ & $0.1 \mathrm{fA}$ \\
\hline 2. Due to differentiating capacitor & $0.5 \mathrm{fA}$ & $0.05 \mathrm{fA}$ & $0.005 \mathrm{fA}$ \\
\hline 3. Due to electrometer & $75.4 \mathrm{fA}$ & $13.6 \mathrm{fA}$ & $3.62 \mathrm{fA}$ \\
\hline 4. Due to measurement repeatability & $2.14 \mathrm{fA}$ & $0.9 \mathrm{fA}$ & $0.1 \mathrm{fA}$ \\
\hline Combined uncertainty & $76.1 \mathrm{fA}$ & $13.6 \mathrm{fA}$ & $3.75 \mathrm{fA}$ \\
\hline Expanded uncertainty $(k=1.96)$ & $149 \mathrm{fA}$ & 26.7 fA & $7.36 \mathrm{fA}$ \\
\hline
\end{tabular}

The online version of the original article can be found under doi:10.1007/s12647-016-0186-0.

*Corresponding author, E-mail: bushra3007@gmail.com 